\begin{tabular}{|c|c|c|}
\hline \multirow{2}{*}{ IDUNAS } & NATURAL \& APPLIED SCIENCES & 2021 \\
& Vol. 4 \\
No. 1 \\
$(38-51)$ \\
\hline
\end{tabular}

\title{
Microbial Activities and Physicochemical Properties of Pesticide Treated Soils and Waters
}

\author{
Research Article \\ Sebiomo Adewole ${ }^{1 * \text { iD }}$, Banjo F. Mary ${ }^{1 * \text { iD }}$ \\ ${ }^{l}$ Department of Biological Sciences, Tai Solarin University of Education Ijagun, Ijebu-Ode. \\ Author E-mails \\ rev20032002@yahoo.com \\ *Correspondance to: Sebiomo Adewole, Department of Biological Sciences, Tai Solarin University of Education Ijagun, Ijebu-Ode. \\ Tel: +234812263934 \\ DOI: 10.38061 idunas.758764
}

Received: 26.06.2020; Accepted: 24.11.2020

\section{Abstract}

The aim of this study is to determine microbial activities and physicochemical properties of pesticide treated soils and waters . Nutrient agar (NA)and Potato Dextrose Agar (PDA) were used for the enumeration of total heterotrophic bacteria and fungi respectively. Soil CO2-evolution was estimated every 5-days for 25 days. Total nitrogen, available phosphorus, dehydrogenase activity, Chemical Oxygen Demand (COD), Biochemical Oxygen Demand (BOD) and Dissolved Oxygen (DO) were also determined . Bacillus subtillis, Bacillus macerans, Pseudomonas aeruginosa, Psedomonas putida and A. niger were of common occurrence in all soil samples. The total bacterial counts in the farmland soils which had received pesticide treatment in Egbe $(9.330 \times 105 \pm 0.278 \mathrm{CFU} / \mathrm{g})$, Ijele $(10.170 \times 105 \pm 0.211 \mathrm{CFU} / \mathrm{g})$ and imaka $(9.47 \times 105 \pm 0.334$ $\mathrm{CFU} / \mathrm{g})$ were higher than control $(7.100 \times 105 \pm 0.177 \mathrm{CFU} / \mathrm{g}, 7.470 \times 105 \pm 0.186 \mathrm{CFU} / \mathrm{g}, 6.72 \times 105 \pm 0.125$ $\mathrm{CFU} / \mathrm{g})$ soil samples respectively. The total fungal counts $(1.130 \times 105 \pm 0.126 \mathrm{CFU} / \mathrm{g}, 0.850 \times 105 \pm 0.050$ $\mathrm{CFU} / \mathrm{g}, 0.680 \times 105 \pm 0.048 \mathrm{CFU} / \mathrm{g}, 1.10 \times 105 \pm 0.037 \mathrm{CFU} / \mathrm{g}$ ) at the point of pollution at Egbe, Ibido, Ijele and Imaka respectively were found to be higher than their respective control soil samples. The BOD ranged from $15.837 \pm 0.187$ to $20.853 \pm 0.254 \mathrm{mg} / \mathrm{L}$. The DO, COD and BOD of the control water samples were significantly $(\mathrm{P} \leq 0.05)$ higher than the values obtained at the point of pollution. This study indicated the extent of microbial and pesticide pollution; further addition of wastes may deteriorate the existing hygienic quality of water in these locations.

Keywords: BOD, COD, DO, Total Nitrogen

\section{INTRODUCTION}

The use of pesticides in agricultural production whilst maintaining water quality is a major challenge in Nigeria. This has become increasingly significant as a result of the role of pesticides for effective production of food crops and industrial raw materials. Pesticides are used to control insects, weeds, and plant diseases which have negative impact on maximum plant growth, development, yields and marketability of crops, thereby ensuring sustainability of food production and availability of food all year 
round (Lugushie and Atabila, 2012). When pesticides are applied on farmlands it can result in the pollution of water bodies by surface runoff, leaching (matrix flow) and preferential flow. Movement of pesticides from soil to water depends on factors such as soil texture, soil organic matter (FAO, 1996; Pierzynski et al., 2000; Filizola et al., 2002; Beitz et al., 1994), topography and rainfall (De Rossi et al., 2003; Tang et al., 2012). Pesticides which are highly adsorbed by soil mineral and organic particles have a lower leaching potential and consequently a high potential for being transported by surface runoff along with the sediments (Cheah et al., 1997).

Accumulation of such toxic water basically into the soil and water ultimately enter the food chain and cause health hazards. These toxic substances are either organic or inorganic compounds (Maibam et al., 2014). A number of quality parameters such as $\mathrm{pH}$, color, turbidity, suspended solids, temperature, conductivity, odor, $\mathrm{COD}, \mathrm{BOD}, \mathrm{DO}$, total nitrogen, total phosphate, total pesticides and Biological properties such as total faecal coliform counts, faecal streptococci counts, Salmonella counts are measured to determine water quality (Maibam et al., 2014).

The developed countries suffer from problems of chemical discharge into the water sources mainly groundwater, while developing countries face problems of agricultural run-off in water sources. Some studies reported the presence of pesticides in the surface water close to agriculture lands (Oudney et al., 2009; Anasco et al., 2010). Pesticides can get into water through drift during pesticides spraying, by runoff from treated area and leaching via the soil. This study determined microbial activities and physicochemical properties of pesticide treated soils and waters.

\section{MATERIALS AND METHODS}

\section{Characteristics of Areas Where the Rivers are Located}

This study was carried out in Odogbolu Local Government Area (Latitude 6.78597 and longitude 3.80511) South Western Nigeria (Figure, 1). The farm lands are located in Egbe (Latitude 6.75, Longitude 3.9528), Ijele (Latitude 6.74, Longitude 3.810739), Ibido (Latitude 6.75, Longitude 3.91667) and Imaka (Latitude 6.75, Longitude 3.9528) all in the same local government area (Figure 1). Each of the farm lands (all the rivers have farmlands that use both insecticides and herbicides close to their banks) were situated close to the bank of rivers. The rivers are used for several activities such as washing, bathing and drinking. Odogbolu has a tropical climate. The summers are much rainier than the winters in Odogbolu. The KöppenGeiger climate classification is Aw. The temperature here averages $27.2^{\circ} \mathrm{C}$. The rainfall in Odogbolu averages $1539 \mathrm{~mm}$. The driest month is December, with $14 \mathrm{~mm}$ of rainfall. The greatest amount of precipitation occurs in June, with an average of $274 \mathrm{~mm}$. The warmest month of the year is March with an average temperature of $29.0{ }^{\circ} \mathrm{C}$. The lowest average temperatures in the year occur in August, when it is around $25.3^{\circ} \mathrm{C}$. 


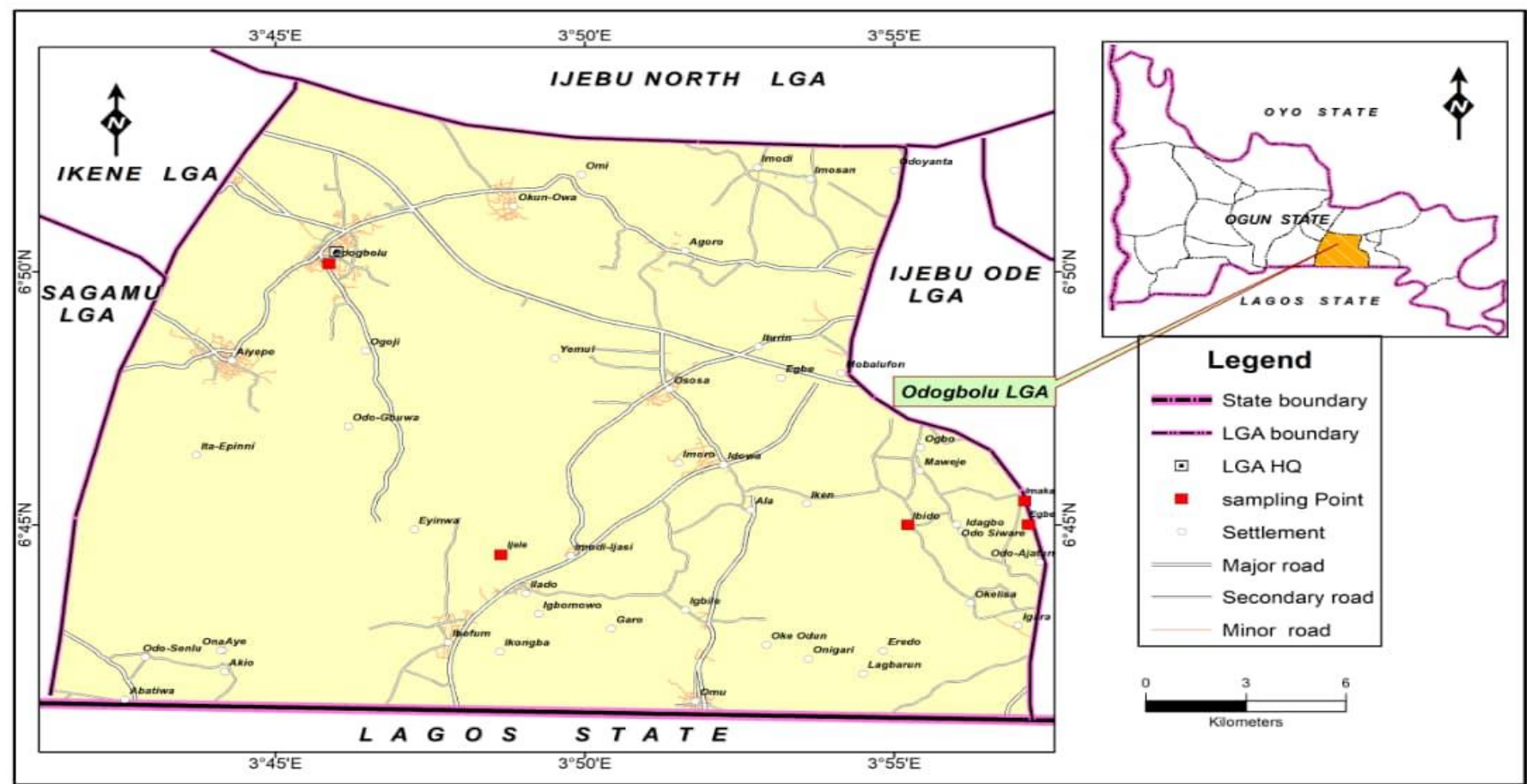

Figure 1. A map showing the longitude and latitude of pollution points.

\section{Pesticides Used on The Farmlands}

A survey of the most applied pesticides in the region was carried out. As a result, insecticide such as: Bentaforce (Bentzone sodium Salt, 40\% SL Bentazothiadiazine), and herbicides which include; Weed cut (Paraquat Dichloride- $276 \mathrm{~g} / \mathrm{L}$ ), Atraforce (Atrazine 80\% wp, $270 \mathrm{~g} / \mathrm{L}$ ) and Force up (GlyphosateIsopropylamine Salt, $360 \mathrm{~g} / \mathrm{L}$ ) which were discovered to be commonly used in the farmlands close to the rivers were chosen for analysis in the present study.

\section{Microbial Isolation, Enumeration and Identification}

Nutrient agar (NA) was used for the enumeration of total heterotrophic bacteria by the pour plate method. Incubation was done at $30^{\circ} \mathrm{C}$ for $24-48 \mathrm{~h}$. Enumeration and isolation of fungi was carried out using Potato Dextrose Agar (PDA) and incubated at $25^{\circ} \mathrm{C}$ for 7 days. Bacterial isolates were characterized based on cultural characteristics, staining reactions and biochemical reactions. Identification was thereafter made with reference to Bergey's Manual of Systemic Bacteriology (1984). Morphological and cultural characteristics were used for fungi identification. The bacteria and fungi that emerged from plates were subcultured repeatedly until pure cultures were obtained. Counts of microorganisms were taken from plates containing 15-150 colonies per plates using the Quebec colony counter and this was used to calculate the number of colony forming units per gram $(\mathrm{cfu} / \mathrm{g})$ in each soil sample.

\section{Microbial Respiration}

Microbial respiration was carried out using the method of Klimek (2012). One hundred grams treated and untreated soil samples were placed in $1000 \mathrm{~mL}$ wide neck screw top glass jars containing $10 \mathrm{~mL}$ of $\mathrm{NaOH} 0.1 \mathrm{~N}$ solution in separate vials. Soil samples were incubated in the dark at $250 \mathrm{C}+0.5$. Soil moisture content was maintained at $60 \%$ water holding capacity by weighing and correcting for any weight loss, using sterile ultra pure water. Soil CO2-evolution was regularly (5-days interval period) estimated 
during the twenty-five days incubation period. $\mathrm{CO} 2$ recovered in each $\mathrm{NaOH}$ solution was measured by titration with $\mathrm{HCl}$, following the addition of $\mathrm{BaCl} 2$. Percentage $\mathrm{CO} 2$ evolved was then calculated.

\section{Determination of Total Nitrogen}

Ten grams of soil was weighed into $250 \mathrm{ml}$ bottle and $100 \mathrm{ml}$ of $2 \mathrm{M} \mathrm{KCl}$ was added, the bottle was stoppered and shaken on a mechanical shaker for 1 hour. The suspension was then filtered through whatman No. 42 filter paper and an aliquot for the analysis of the nitrogen form required was taken and refrigerated. Available nitrogen $\left(\mathrm{NH}_{4}-\mathrm{N}\right.$ and $\left.\mathrm{NO}_{3}-\mathrm{N}\right)$ in soil samples were then determined using the method of Landon (1984, 1991). Total nitrogen in soil samples was determined using macro-Kjeldhal distillation method. The nitrogen in the distillate was then determined by titration (Page et al., 1982).

\section{Determination of Available Phosphorus in Soil}

Five grams of air-dried soil sample (passed through $2 \mathrm{~mm}$ sieve) was weighed into centrifuge tube and $20 \mathrm{ml}$ of extracting solution added. The mixture was then shaken for 1 minute on a mechanical shaker and centrifuged at 2000rpm for 15 minutes. Two millilitres of clear supernatant was then dispensed into $20 \mathrm{ml}$ test tube with a pipette. Five millilitres of distilled water and $2 \mathrm{ml}$ of ammonium molybdate solution was then added. The content was then mixed properly and $1 \mathrm{ml}$ of $\mathrm{SnCl}_{2} .2 \mathrm{H}_{2} \mathrm{O}$ dilute solution was then added and mixed again. After 5 minutes $\%$ transmittance was measured on spectronic-20 electrophotometer at $660 \mathrm{~nm}$ wave length. Standard curve within the range of $0.1 \mu \mathrm{gP} / \mathrm{mL}$ (ppm P) was then prepared. optical density of the standard solution was plotted against the ppm $\mathrm{P}$ and the content of the extractable $\mathrm{P}$ in the soil was calculated.

\section{Determination of Dehydrogenase Activity}

$6 \mathrm{~g}$ of soil and $6 \mathrm{ml}$ of water samples were dispensed separately into $500 \mathrm{ml}$ conical flasks. $30 \mathrm{ml}$ glucose, $1 \mathrm{ml}$ of 2,3,5-triphenyl tetrazolium chloride (TTC) solution plus $2.5 \mathrm{ml}$ of distilled water were added and shaken on a shaker for $5 \mathrm{~min}$. The mixtures were then filtered through a double layered filter paper into $250 \mathrm{ml}$ conical flask having formed 1,3,5-triphenyl formazan (TPF). A stock solution of $0.2 \mu \mathrm{mol} / \mathrm{mL}$ of TPF was prepared by dissolving $0.03 \mathrm{~g}$ TPF in $500 \mathrm{ml}$ methanol. Working standard solutions of range 0.004 $-0.10 \mu \mathrm{mol} / \mathrm{mL}$ TPF were prepared from the stock solution to get the gradient factor. The absorbances of sample extract above and that of different working standard solutions were read on a UV/V Cecil Spectrophotometer at a wavelength of $485 \mathrm{~nm}$.

\section{Determination of Dissolved Oxygen (DO)}

Dissolved Oxygen was determined using the method of APHA (1998). This was done using Winkler's method. In this procedure, an excess of Manganese (II) salt, iodide (I-) and hydroxide (OH-) ions were added to the samples causing a white precipitate of $\mathrm{Mn}(\mathrm{OH}) 2$ to form. This precipitate was then oxidized by the dissolved oxygen in the water sample into a brown Manganese precipitate. In the next step, a strong acid (either hydrochloric acid or sulphuric acid) was added to acidify the solution. The brown precipitate then converted the iodide ion (I-) to iodine. The amount of DO was directly proportional to the titration of iodine with a thiosulphate solution. In this study, 300ml BOD bottles were filled with the samples respectively, $2 \mathrm{ml}$ of manganese sulphate and $2 \mathrm{ml}$ of alkali-iodide-azide solution added by inserting a pipette just below the surface of the liquid. The bottles were stoppered to avoid the introduction of air and were mixed by inverting several times. The bottles were left to stand for a few minutes. The presence of oxygen was indicated by the formation of a brownish orange precipitate. Two millimeters (2ml) of $\mathrm{H} 2 \mathrm{SO} 4$ was added to the samples. It was mixed again by inverting to dissolve the precipitate. Two hundred and one 
milliliter of the sample was then measured into a clean $250 \mathrm{ml}$ conical flask and titrated against sodium thiosulphate Solution $(\mathrm{Na} 2 \mathrm{~S} 2 \mathrm{O} 35 \mathrm{H} 2 \mathrm{O})$ using the starch indicator until the solution turned colorless.

\section{Calculation:}

$\mathrm{DO}(\mathrm{mg} / \mathrm{L})=[16000 \times \mathrm{M} \mathrm{xV}] /\left[\mathrm{V}_{2} / \mathrm{V}_{1}(\mathrm{v} 1-2)\right]$

Where $=$ Molarity of thiosulpahte used.

$\mathrm{V}=$ volume of thiosulphate used for titration

$\mathrm{V} 1=$ Volume of bottle with stopper

$\mathrm{V} 2=$ Volume of aliquot taken for titration.

\section{Chemical Oxygen Demand (COD)}

Determination of COD was carried out according to the method described by Ademoroti (1996). $0.4 \mathrm{~g} \mathrm{HgSO} 4,20 \mathrm{ml}$ of water sample, $2 \mathrm{ml}$ sulphuric acid and $10 \mathrm{ml}$ of standard $\mathrm{K} 2 \mathrm{Cr} 2 \mathrm{O} 7$ solution and some glass beads was placed into a reflux with gentle swirling, $30 \mathrm{ml}$ of Ag2SO reagent was slowly added, and refluxed for about two hours and cooled. The condenser was then washed with distilled water into Erlenmeyer flask and diluted to $150 \mathrm{ml}$ with distilled water. The solution was allowed to cool to room temperature. The solution was then titrated with standard ferrous ammonium sulphate (FAS) using ferroin indicator.

The blank titration was carried out as above but using distilled water in place of the sample. The COD of the water sample was calculated from the following expression.

$$
\begin{gathered}
\mathrm{COD}(\mathrm{mg} / \mathrm{L})=(\mathrm{Vb}-\mathrm{Vs}) \times \mathrm{M} \times 16000 \\
\mathrm{ml} \text { of sample }
\end{gathered}
$$

where $\mathrm{Vb}=$ Volume of FAS for Blank;

Vs = Volume of FAS for sample;

$\mathrm{M}=$ Molarity of FAS.

\section{Determination of Biochemical Oxygen Demand (BOD)}

The method involves filling the samples to overflowing, in an airtight bottle of the specified size and incubating it at the specified temperature for 5days. DO was measured initially and after incubation and the BOD was computed from the difference between initial and final DO. Because the initial DO was determined shortly after the dilutions was added, all oxygen uptake occurring after this measurement was included in the BOD measurement. One Millimeter $(1 \mathrm{ml})$ of $\mathrm{MgSO} 4, \mathrm{CaCl} 2$, phosphate buffer, $\mathrm{FeCl} 3$ were added to $1 \mathrm{~L}$ of water. The solution was then shaken thoroughly to saturate the dissolved oxygen. This solution was used to dilute samples. One hundred millimeters $(100 \mathrm{ml})$ of the samples were measured into different one Liter flasks and were made up to (1L) mark with the dilution water previously prepared. The dilution sample solution was then dispensed into BOD bottles and subsequently incubated at $20 \mathrm{oC}$ in the dark for 5 days (APHA, 1998).

Or

$$
\text { BOD5 }=\text { DOi }- \text { DOf }
$$

$$
\begin{aligned}
& \text { (Doi - Dof) } \times \text { vol of BOD bottle } \\
& \text { vol of water sample }
\end{aligned}
$$

\section{Statistical Analysis}

Pearson's correlation coefficient between the measured variables was determined. Pearson's correlation coefficients were calculated at $\mathrm{P} \leq 0.01$ and $\mathrm{P} \leq 0.05$. The data were statistically analysed, with SPSS version 20 software, using a one-way analysis of variance (ANOVA). 


\section{RESULTS}

Presented in Table 1, are bacteria and fungi isolated from the soil samples obtained from the various farmlands. Bacillus subtillis, Bacillus macerans, Pseudomonas aeruginosa, and Pseudomonas putida were prevalent in all the soil samples analyzed. Aspergillus species were isolated in all the soils analyzed. Aspergillus niger was isolated in all soil samples analyzed except Ijele, Imaka and Ibido points of pollution (Table 2).

Table 1. Bacteria and fungi isolated from soil samples in selected locations

\section{SOIL SAMPLE \\ BACTERIA}

\begin{tabular}{|c|c|}
\hline Ibido Control & $\begin{array}{l}\text { B. cereus, B. macerans, B. subtilis, } P \text {. aureginosa, S. marscences } P \text {. } \\
\text { putida, S. aureus, S. faccium, }\end{array}$ \\
\hline Ibido POPL & $\begin{array}{l}\text { P. putrefaciens, B. linchinefomis, B. macerans, B. subtilis, B. cereus, } M \text {. } \\
\text { acidiophilus, M. luteus, P. putida, S. aureus }\end{array}$ \\
\hline Imaka Control & $\begin{array}{l}\text { B. subtilis, B. macerans, Micro. acidiophilus, } P \text {. aureginosa, } P \text {. } \\
\text { vulgaricus, } S \text {. aureus }\end{array}$ \\
\hline Imaka POPL & $\begin{array}{l}\text { B. cereus, B. macerans, B. putrefaciens, } P \text {. florescences, } P \text {. mirabilis, } P \text {. } \\
\text { vulgaricus, } S \text {. faecalis, }\end{array}$ \\
\hline Egbe Control & $\begin{array}{l}\text { Aerobacter aerogenes, B. subtilis, } M . \text { acidiophilus, } M . \text { luteus, } P \text {. } \\
\text { aureginosa, } P \text {. putida, }\end{array}$ \\
\hline Egbe POPL & $\begin{array}{l}\text { Aerobacter aerogenes, } B . \text { macerans, } B \text {. subtilis, Clostridium sp, } P \text {. } \\
\text { aureginosa, } P . \text { florenscences, } P . \text { putida, S. lactis, }\end{array}$ \\
\hline Ijele Control & $\begin{array}{l}\text { B. macerans, B. subtilis, M. luteus, } P \text {. aureginosa, } P \text {. vulgaricus, } S \text {. } \\
\text { aureus, S. lactis, }\end{array}$ \\
\hline
\end{tabular}

SOIL SAMPLE FUNGI

Ibido Control Ibido POPL Imaka Control Imaka POPL Egbe Control Egbe POPL Ijele Control Ijele POPL
A. niger, P. oxalicum, F. oxysporum.

A. tamarii, F. compacticum, F. oxysporum,

A. niger, F. compacticum, F. oxysporum, P. oxalicum.

A. tamarii, A. tereus, F. oxysporum, P. chrysogenum, P. oxalicum.

A. niger, A. tamarii, A. tereus, $F$. compacticum, $P$. citrinium, $P$. oxalicum

A. niger, A. fumigatus, A. flavus, A. terreus, F. equsetti, $P$. oxalicum

A. niger, A. tamarii, F. oxysporum, P.oxalicum.

A. fumigatus, A. tamarii, A. tereus, F. oxysporum, $P$. chrysogenum, $P$. oxalicum.

\section{POPL $=$ Point of pollution}

Figure 2a, 2b, 2c, 2d shows the picture of the Egbe, Ibido, Ijele and imaka rivers. The Egbe River is used for several activities such as fishing, washing of clothes, bathing and drinking. There have also been reports of the presence of Alligator Crocodiles in this river. The rivers are constantly polluted with human faeces and urine. 
a)

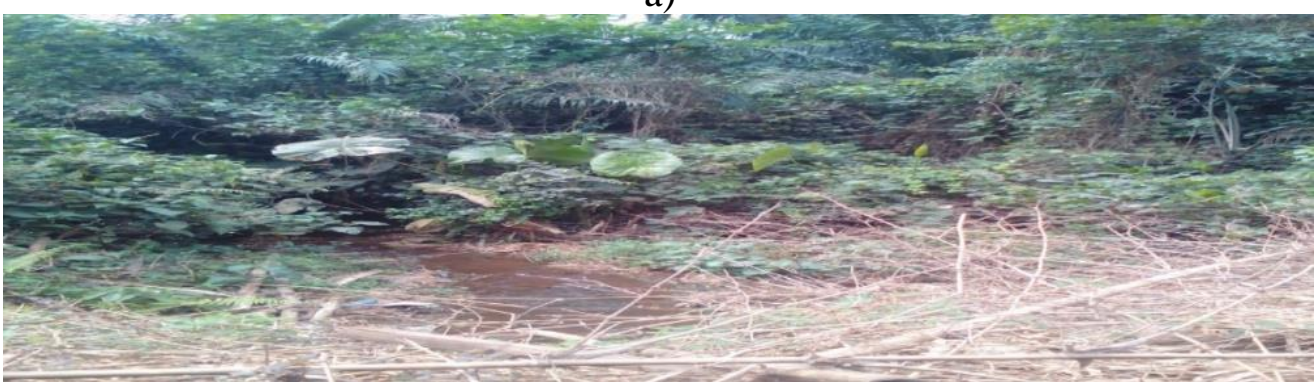

b)

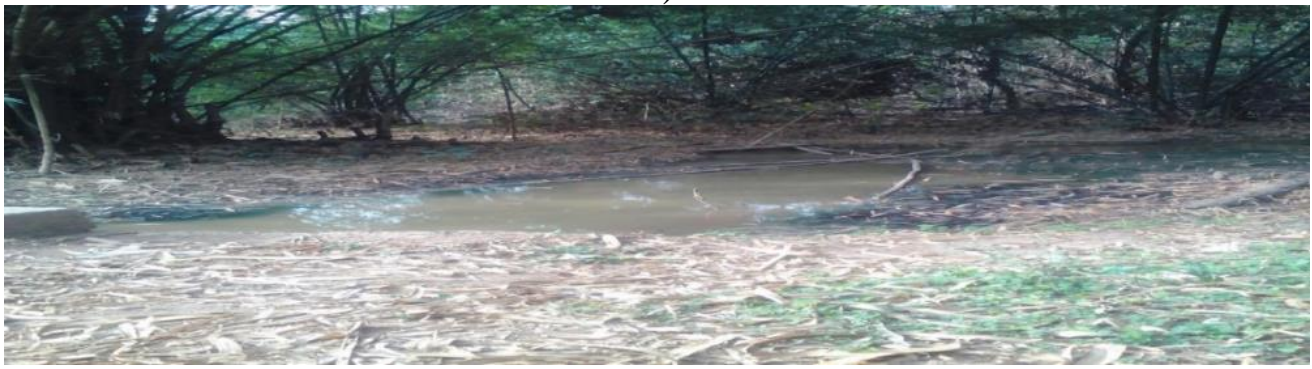

c)

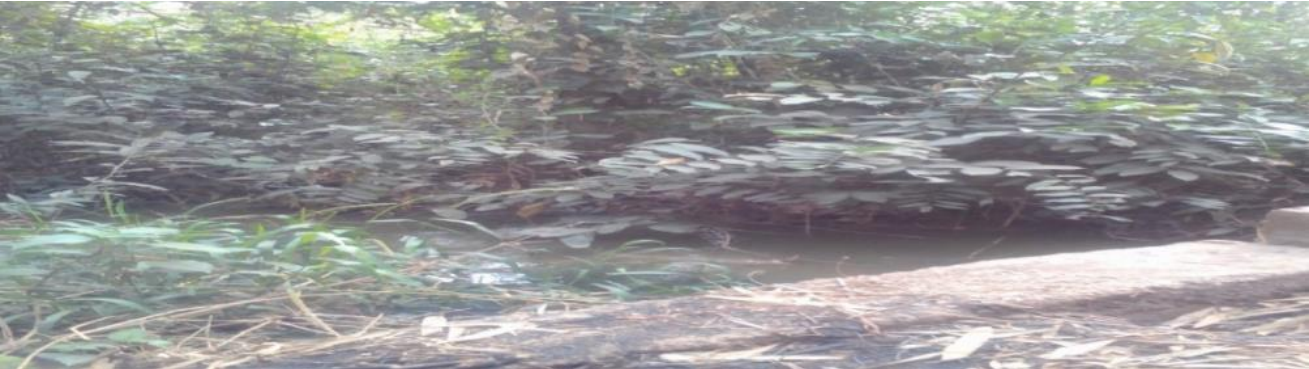

d)

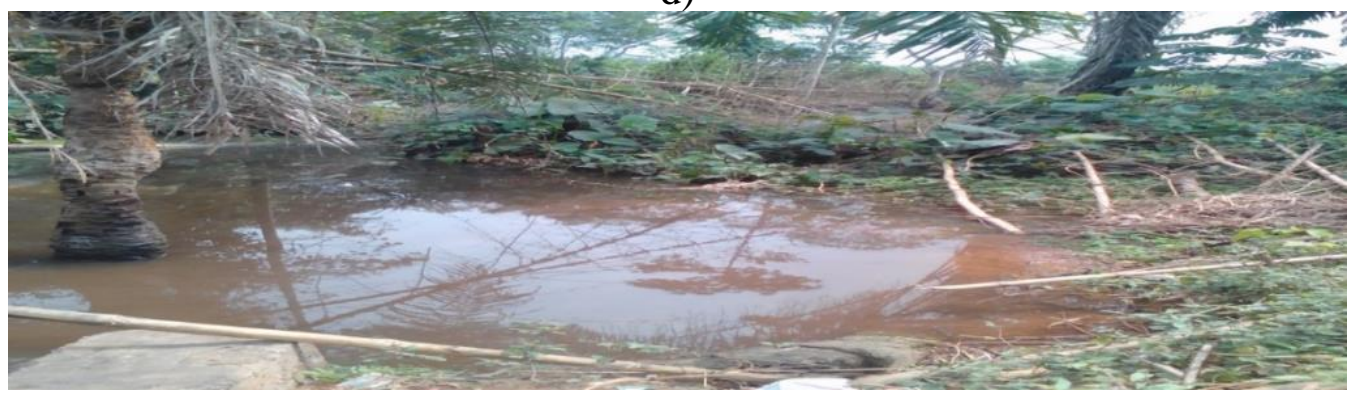

Figure 2. Photographs showing rivers used in this study (a) Egbe river (b) Ibido river (c) Ijele river (d) Imaka river.

In Table 2a, there were significant changes $(\mathrm{P} \leq 0.05)$ in the microbial counts, microbial activity (microbial respiration and dehydrogenase activity), available phosphorus, total nitrogen and pesticide concentration of the polluted soil samples in all the locations analyzed. The total bacterial counts in the farmland soils which had received pesticide treatment in Egbe $\left(9.330 \times 10^{5} \pm 0.278 \mathrm{CFU} / \mathrm{g}\right)$, Ijele $(10.170$ $\left.\times 10^{5} \pm 0.211 \mathrm{CFU} / \mathrm{g}\right)$ and $\operatorname{imaka}\left(9.47 \times 10^{5} \pm 0.334 \mathrm{CFU} / \mathrm{g}\right)$ were higher than control $\left(7.100 \times 10^{5} \pm 0.177\right.$ $\mathrm{CFU} / \mathrm{g}, 7.470 \times 10^{5} \pm 0.186 \mathrm{CFU} / \mathrm{g}, 6.72 \times 10^{5} \pm 0.125 \mathrm{CFU} / \mathrm{g}$ ) soil samples respectively. In Ibido farmland the total bacterial count $\left(8.150 \times 10^{5} \pm 0.326 \mathrm{CFU} / \mathrm{g}\right)$ in the pesticide treated soils was lower than that obtained in the control soil samples $\left(11.100 \times 10^{5} \pm 0.313 \mathrm{CFU} / \mathrm{g}\right)$. The total coliform count in the pesticide treated soils of Ibido $\left(5.470 \times 10^{5} \pm 0.109 \mathrm{CFU} / \mathrm{g}\right)$, Ijele $\left(6.030 \times 10^{5} \pm 0.095 \mathrm{CFU} / \mathrm{g}\right)$ and Imaka $(6.58$ $\left.\times 10^{5} \pm 0.070 \mathrm{CFU} / \mathrm{g}\right)$ were found to be higher than their control soil samples $\left(4.320 \times 10^{5} \pm 0.117,5.400 \times 10^{5}\right.$ $\pm 0.052,4.05 \pm 0.120 \mathrm{CFU} / \mathrm{g}$ ) respectively. Meanwhile in the Egbe farmlands the total coliform count in the control $\left(5.450 \times 10^{5} \pm 0.056 \mathrm{CFU} / \mathrm{g}\right)$ soil samples was higher than that of the pesticide treated soils $(4.400$ 
$\left.\times 10^{5} \pm 0.291 \mathrm{CFU} / \mathrm{g}\right)$. The total fungal counts $\left(1.130 \times 10^{5} \pm 0.126 \mathrm{CFU} / \mathrm{g}, 0.850 \times 10^{5} \pm 0.050 \mathrm{CFU} / \mathrm{g}, 0.680\right.$ $\times 10^{5} \pm 0.048 \mathrm{CFU} / \mathrm{g}, 1.10 \times 10^{5} \pm 0.037 \mathrm{CFU} / \mathrm{g}$ ) at the point of pollution at Egbe, Ibido, Ijele and Imaka respectively were found to be higher than their respective control soil samples. Soils that have received pesticide treatment showed higher microbial counts except the total coliform count (Egbe) and total bacterial count (Ibido). Microbial respiration $\left(1.470 \pm 0.029 \mu \mathrm{gg}^{-1}, 1.190 \pm 0.007 \mu \mathrm{gg}^{-1}, 1.300 \pm 0.010 \mu \mathrm{gg}^{-1}\right.$, $\left.1.29 \pm 0.007 \mu \mathrm{gg}^{-1}\right)$ in soils that received pesticide treatment in Egbe, Ibido, Ijele and Imaka respectively were higher than their respective control soil samples $\left(0.600 \pm 0.009 \mu \mathrm{gg}^{-1}, 1.050 \pm 0.022 \mu \mathrm{gg}^{-1}, 0.820 \pm 0.026\right.$ $\left.\mu \mathrm{gg}^{-1}, 0.63 \pm 0.042 \mu \mathrm{gg}^{-1}\right)$. The available phosphorus, dehydrogenase activities and total nitrogen content of soil samples at the point of pollution, in all the farmlands analyzed in this study, were higher than their control soil samples. All the farmland soils analyzed in this study showed the presence of the three herbicides (Weed cut, Atraforce, Force up) and insecticide (Bentaforce). The herbicide Force up had the highest concentration $\left(0.089 \pm 0.001 \mu \mathrm{g} \mathrm{g}^{-1}\right)$ at Imaka farmland.

Presented in Table $2 \mathrm{~b}$ are the microbial counts, microbial activity (microbial respiration and dehydrogenase activity), available phosphorus, total nitrogen, dissolved oxygen, biochemical oxygen demand and chemical oxygen demand of water polluted with pesticides. There were significant changes in all the variables analyzed in Table 2 . The total bacterial counts and the total fungal counts of the control water samples obtained from Egbe, Ijele, Ibido and Imaka were found to be lower than the counts obtained at the point of pollution. The highest total bacterial count of $9.933 \times 10^{5} \pm 0.305 \mathrm{CFU} / \mathrm{g}$ was obtained in polluted water obtained at Imaka, while the highest fungal count of $0.567 \times 10^{5} \pm 0.042 \mathrm{CFU} / \mathrm{g}$ was obtained at the Ijele polluted water samples. The total coliform count of the control water samples obtained at Ibido, Ijele and Imaka were found to be higher than the values obtained at the point of pollution. Meanwhile the total coliform count of the control water samples obtained at Egbe were found to be lower than the total coliform count obtained at the point of pollution. The highest coliform count of $6.733 \times 10^{5} \pm 0.235 \mathrm{CFU} / \mathrm{g}$ was obtained in the water samples obtained at the point of pollution in Egbe. Microbial respiration, dehydrogenase activities and total nitrogen were found to be highest at the point of pollution of the water samples compared to the control. The highest microbial respiration, dehydrogenase activity and total nitrogen values of $0.165 \pm 0.002 \mu \mathrm{gg}^{-1}, 0.012 \pm 0.000 \mu \mathrm{gg}^{-1}$ and $0.017 \pm 0.001 \%$ respectively were obtained at the point of pollution in Ijele. Available phosphorus was found to be highest at the point of pollution of the water samples compared to the control. The highest available phosphorus value of $7.767 \pm 0.056 \%$ was obtained at the point of water pollution at Imaka. The dissolved oxygen, chemical oxygen demand and the biochemical oxygen demand of the control water samples were significantly $(\mathrm{P} \leq 0.05)$ higher than the values obtained at the point of pollution. The highest dissolved oxygen value of $6.183 \pm 0.031 \mathrm{mg} \mathrm{l}^{-1}$ was obtained in the control water samples of Imaka. Meanwhile the highest biochemical oxygen demand value of $20.853 \pm 0.254 \mathrm{mg} \mathrm{l}^{-1}$ was obtained in the control water samples of Egbe. The BOD ranges from $15.837 \pm 0.187$ to $20.853 \pm 0.254 \mathrm{mg} / \mathrm{L}$.

Table 2a. Microbial counts, microbial activity (microbial respiration and dehydrogenase activity), available phosphorus, total nitrogen and pesticide concentration in polluted soils.

\begin{tabular}{llcccc}
\hline & \multicolumn{1}{c}{ EGBE } & IBIDO & IJELE & IMAKA \\
\hline $\mathrm{TBC}\left(\times 10^{5}\right.$ & CONT & $7.100 \pm 0.177$ & $11.100 \pm 0.313$ & $7.470 \pm 0.186$ & $6.72 \pm 0.125$ \\
$\mathrm{CFU} / \mathrm{g})$ & POPL & $9.330 \pm 0.278$ & $8.150 \pm 0.326$ & $10.170 \pm 0.211$ & $9.47 \pm 0.334$ \\
$\mathrm{TCC}\left(\times 10^{5} \mathrm{CFU}\right.$ & $\mathrm{CONT}$ & $5.450 \pm 0.056$ & $4.320 \pm 0.117$ & $5.400 \pm 0.052$ & $4.05 \pm 0.120$ \\
$/ \mathrm{g})$ & POPL & $4.400 \pm 0.291$ & $5.470 \pm 0.109$ & $6.030 \pm 0.095$ & $6.58 \pm 0.070$ \\
$\mathrm{TFC}\left(\times 10^{5} \mathrm{CFU}\right.$ & CONT & $0.350 \pm 0.050$ & $0.470 \pm 0.042$ & $0.370 \pm 0.021$ & $0.55 \pm 0.050$ \\
$/ \mathrm{g})$ & POPL & $1.130 \pm 0.126$ & $0.850 \pm 0.050$ & $0.680 \pm 0.048$ & $1.10 \pm 0.037$ \\
$\mathrm{MR}\left(\mu \mathrm{gg}^{-1}\right)$ & CONT & $0.600 \pm 0.009$ & $1.050 \pm 0.022$ & $0.820 \pm 0.026$ & $0.63 \pm 0.042$ \\
$\mathrm{AP}\left(\mathrm{mgkg}^{-1}\right)$ & POPL & $1.470 \pm 0.029$ & $1.190 \pm 0.007$ & $1.300 \pm 0.010$ & $1.29 \pm 0.007$ \\
& CONT & $6.420 \pm 0.100$ & $6.540 \pm 0.031$ & $5.680 \pm 0.107$ & $6.35 \pm 0.019$ \\
\hline
\end{tabular}




\begin{tabular}{llllll}
\hline & POPL & $8.790 \pm 0.054$ & $7.800 \pm 0.196$ & $7.890 \pm 0.342$ & $8.61 \pm 0.023$ \\
$\mathrm{DEH}\left(\mu \mathrm{gg}^{-1}\right)$ & CONT & $0.010 \pm 0.001$ & $0.010 \pm 0.000$ & $0.010 \pm 0.001$ & $0.01 \pm 0.001$ \\
& POPL & $0.030 \pm 0.002$ & $0.020 \pm 0.002$ & $0.040 \pm 0.001$ & $0.03 \pm 0.001$ \\
$\mathrm{TN}(\%)$ & CONT & $0.050 \pm 0.002$ & $0.050 \pm 0.002$ & $0.050 \pm 0.001$ & $0.04 \pm 0.001$ \\
& POPL & $0.080 \pm 0.001$ & $0.080 \pm 0.001$ & $0.070 \pm 0.003$ & $0.07 \pm 0.002$ \\
$\mathrm{BF}\left(\mu \mathrm{g} \mathrm{g}^{-1}\right)$ & CONT & $0.001 \pm 0.000$ & $0.002 \pm 0.000$ & $0.002 \pm 0.000$ & $0.001 \pm 0.000$ \\
& POPL & $0.018 \pm 0.001$ & $0.034 \pm 0.015$ & $0.022 \pm 0.001$ & $0.012 \pm 0.001$ \\
$\mathrm{WC}\left(\mu \mathrm{g} \mathrm{g}^{-1}\right)$ & CONT & $0.002 \pm 0.000$ & $0.001 \pm 0.000$ & $0.001 \pm 0.000$ & $0.001 \pm 0.000$ \\
$\mathrm{AF}\left(\mu \mathrm{g} \mathrm{g}^{-1}\right)$ & POPL & $0.038 \pm 0.001$ & $0.057 \pm 0.002$ & $0.057 \pm 0.001$ & $0.042 \pm 0.001$ \\
& CONT & $0.001 \pm 0.000$ & $0.001 \pm 0.000$ & $0.001 \pm 0.000$ & $0.001 \pm 0.000$ \\
$\mathrm{FU}\left(\mu \mathrm{g} \mathrm{g}^{-1}\right)$ & POPL & $0.025 \pm 0.001$ & $0.020 \pm 0.001$ & $0.053 \pm 0.001$ & $0.035 \pm 0.002$ \\
& CONT & $0.001 \pm 0.000$ & $0.001 \pm 0.000$ & $0.001 \pm 0.000$ & $0.001 \pm 0.000$ \\
\hline
\end{tabular}

$\mathrm{TBC}=$ Total Bacterial Count, $\mathrm{TCC}=$ Total Coliform Count, $\mathrm{TFC}=$ Total Fungal count $\mathrm{MR}=$ Microbial respiration, $\mathrm{AP}=$ Available Phosphorus, $\mathrm{DEH}=$ Dehydrogenase Activity, $\mathrm{TN}=$ Total Nitrogen, $\mathrm{BF}=$ Benta Force, $\mathrm{WC}=$ Weed Cut, $\mathrm{AF}=$ Atra Force, FU $=$ Force Up, CONT $=$ Control, $\mathrm{POPL}=$ Point of Pollution

Table 2b. Microbial counts, microbial activity and physicochemical parameters of water polluted with pesticides

\begin{tabular}{llcccc}
\hline & & EGBE & IBIDO & IJELE & IMAKA \\
\hline $\mathrm{TBC}$ & CONT & $4.617 \pm 0.048$ & $5.350 \pm 0.123$ & $4.900 \pm 0.277$ & $4.933 \pm 0.292$ \\
$\left(\times 10^{5} \mathrm{CFU} / \mathrm{g}\right)$ & POPL & $8.667 \pm 0.099$ & $7.850 \pm 0.214$ & $8.517 \pm 0.335$ & $9.933 \pm 0.305$ \\
$\mathrm{TCC}$ & CONT & $3.783 \pm 0.105$ & $4.050 \pm 0.120$ & $4.667 \pm 0.112$ & $3.600 \pm 0.058$ \\
$\left(\times 10^{5} \mathrm{CFU} / \mathrm{g}\right)$ & POPL & $6.733 \pm 0.235$ & $1.367 \pm 0.096$ & $1.450 \pm 0.062$ & $1.717 \pm 0.040$ \\
$\mathrm{TFC}$ & CONT & $0.233 \pm 0.021$ & $0.233 \pm 0.021$ & $0.233 \pm 0.021$ & $0.233 \pm 0.021$ \\
$\left(\times 10^{5} \mathrm{CFU}^{\mathrm{g}}\right)$ & POPL & $0.533 \pm 0.042$ & $0.500 \pm 0.045$ & $0.567 \pm 0.042$ & $0.467 \pm 0.042$ \\
$\mathrm{MR}\left(\mu \mathrm{gg}^{-1}\right)$ & CONT & $0.007 \pm 0.000$ & $0.109 \pm 0.001$ & $0.005 \pm 0.000$ & $0.039 \pm 0.020$ \\
& POPL & $0.154 \pm 0.001$ & $0.129 \pm 0.003$ & $0.165 \pm 0.002$ & $0.144 \pm 0.001$ \\
$\mathrm{AP}\left(\mathrm{mgkg}^{-1}\right)$ & CONT & $5.700 \pm 0.037$ & $5.810 \pm 0.026$ & $5.433 \pm 0.173$ & $5.287 \pm 0.105$ \\
& POPL & $7.547 \pm 0.193$ & $6.875 \pm 0.022$ & $7.600 \pm 0.228$ & $7.767 \pm 0.056$ \\
$\mathrm{DEH}\left(\mu \mathrm{gg}^{-1}\right)$ & CONT & $0.003 \pm 0.000$ & $0.003 \pm 0.000$ & $0.003 \pm 0.000$ & $0.003 \pm 0.000$ \\
& POPL & $0.010 \pm 0.001$ & $0.005 \pm 0.000$ & $0.012 \pm 0.000$ & $0.008 \pm 0.001$ \\
$\mathrm{TN}(\%)$ & CONT & $0.003 \pm 0.000$ & $0.004 \pm 0.000$ & $0.003 \pm 0.000$ & $0.003 \pm 0.000$ \\
& POPL & $0.012 \pm 0.001$ & $0.007 \pm 0.000$ & $0.017 \pm 0.001$ & $0.010 \pm 0.001$ \\
$\mathrm{DO}\left(\mathrm{mg} \mathrm{l}^{-1}\right)$ & CONT & $6.848 \pm 0.132$ & $7.237 \pm 0.107$ & $6.877 \pm 0.023$ & $6.970 \pm 0.030$ \\
& POPL & $5.690 \pm 0.038$ & $6.033 \pm 0.080$ & $5.578 \pm 0.058$ & $6.183 \pm 0.031$ \\
$\mathrm{BOD}\left(\mathrm{mg} \mathrm{l}^{-1}\right)$ & CONT & $20.853 \pm 0.254$ & $19.267 \pm 0.377$ & $19.150 \pm 0.316$ & $20.567 \pm 0.362$ \\
& POPL & $16.270 \pm 0.115$ & $15.837 \pm 0.187$ & $16.117 \pm 0.128$ & $16.150 \pm 0.188$ \\
$\mathrm{COD}\left(\mathrm{mg} \mathrm{l}^{-1}\right)$ & CONT & $39.833 \pm 0.470$ & $40.217 \pm 0.554$ & $41.567 \pm 0.451$ & $40.440 \pm 0.350$ \\
& POP & $28.100 \pm 0.241$ & $26.033 \pm 0.401$ & $26.300 \pm 0.260$ & $28.950 \pm 0.433$ \\
\hline
\end{tabular}

$\mathrm{TBC}=$ Total Bacterial Count, $\mathrm{TCC}=$ Total Coliform Count, $\mathrm{TFC}=$ Total Fungal count $\mathrm{MR}=\mathrm{Microbial}$ respiration, $\mathrm{AP}=$ Available Phosphorus, $\mathrm{DEH}=$ Dehydrogenase Activity, $\mathrm{TN}=$ Total Nitrogen, $\mathrm{DO}=$ Dissolved Oxygen, BOD $=$ Biochemical Oxygen Demand, $\mathrm{COD}=$ Chemical Oxygen Demand. $\mathrm{CONT}=$ Control, POPL $=$ Point of pollution.

In Tables 3a, 3b, 3c and 3d, Dissolved oxygen, biochemical oxygen demand and chemical oxygen demand showed strong negative correlations with total bacterial count and total fungal count in all locations 
examined. The strongest correlation of dissolved oxygen with total bacterial $(\mathrm{r}=-0.936 ; \mathrm{P} \leq 0.01)$ count and total fungal count $(\mathrm{r}=-0.827 ; \mathrm{P} \leq 0.01)$ occurred in Imaka water samples, while the strongest correlation of biochemical oxygen demand with total bacterial $(\mathrm{r}=--0.988 ; \mathrm{P} \leq 0.01)$ count and total fungal count $(\mathrm{r}=-0.914$; $\mathrm{P} \leq 0.01$ ) occurred in Egbe water samples.

Table 3a. Correlations of selected variables in Ibido water sample

\begin{tabular}{lccllllllll}
\hline & DO & BOD & COD & TBC & TCC & TFC & MR & AP & DEH & TN \\
\hline DO & & $0.774^{* *}$ & $0.916^{* *}$ & $-0.908^{* *}$ & $0.958^{* *}$ & $-0.736^{* *}$ & $-0.818^{* *}$ & $-0.930^{* *}$ & $-0.799^{* *}$ & $-0.881^{* *}$ \\
BOD & $0.774^{* *}$ & & $0.950^{* *}$ & $-0.903^{* *}$ & $0.892^{* *}$ & $-0.878^{* *}$ & $-0.886^{* *}$ & $-0.928^{* *}$ & $-0.970^{* *}$ & $-0.919^{* *}$ \\
COD & $0.916^{* *}$ & $0.950^{* *}$ & & $-0.945^{* *}$ & $0.963^{* *}$ & $-0.815^{* *}$ & $-0.938^{* *}$ & $-0.973^{* *}$ & $-0.963^{* *}$ & $-0.967^{* *}$ \\
TBC & $-0.908^{* *}$ & $-0.903^{* *}$ & $-0.945^{* *}$ & & $-0.931^{* *}$ & $0.819^{* *}$ & $0.875^{* *}$ & $0.945^{* *}$ & $0.882^{* *}$ & $0.950^{* *}$ \\
TCC & $0.958^{* *}$ & $0.892^{* *}$ & $0.963^{* *}$ & $-0.931^{* *}$ & & $-0.845^{* *}$ & $-0.837^{* *}$ & $-0.976^{* *}$ & $-0.882^{* *}$ & $-0.892^{* *}$ \\
TFC & $-0.736^{* *}$ & $-0.878^{* *}$ & $-0.815^{* *}$ & $0.819^{* *}$ & $-0.845^{* *}$ & & $0.721^{* *}$ & $0.893^{* *}$ & $0.839^{* *}$ & $0.752^{* *}$ \\
MR & $-0.818^{* *}$ & $-0.886^{* *}$ & $-0.938^{* *}$ & $0.875^{* *}$ & $-0.837^{* *}$ & $0.721^{* *}$ & & $0.895^{* *}$ & $0.958^{* *}$ & $0.960^{* *}$ \\
AP & $-0.930^{* *}$ & $-0.928^{* *}$ & $-0.973^{* *}$ & $0.945^{* *}$ & $-0.976^{* *}$ & $0.893^{* *}$ & $0.895^{* *}$ & & $0.939^{* *}$ & $0.929^{* *}$ \\
DEH & $-0.799^{* *}$ & $-0.970^{* *}$ & $-0.963^{* *}$ & $0.882^{* *}$ & $-0.882^{* *}$ & $0.839^{* *}$ & $0.958^{* *}$ & $0.939^{* *}$ & & $0.943^{* *}$ \\
TN & $-0.881^{* *}$ & $-0.919^{* *}$ & $-0.967^{* *}$ & $0.950^{* *}$ & $-0.892^{* *}$ & $0.752^{* *}$ & $0.960^{* *}$ & $0.929^{* *}$ & $0.943^{* *}$ & \\
\hline
\end{tabular}

$\mathrm{TBC}=$ Total Bacterial Count, $\mathrm{TCC}=$ Total Coliform Count, $\mathrm{TFC}=$ Total Fungal count $\mathrm{MR}=$ Microbial respiration, $\mathrm{AP}=$ Available Phosphorus, $\mathrm{DEH}=$ Dehydrogenase Activity, $\mathrm{TN}=$ Total Nitrogen, $\mathrm{DO}=$ Dissolved Oxygen, $\mathrm{BOD}=$ Biochemical Oxygen Demand, $\mathrm{COD}=\mathrm{Chemical}$ Oxygen Demand. ${ }^{* *}$ Correlation is significant at the 0.01 level (2-tailed), ${ }^{*}$ Correlation is significant at the 0.05 level (2-tailed).

Table 3b. Correlations of selected variables in Egbe water sample

\begin{tabular}{lcccccccccc}
\hline \multicolumn{1}{c}{ DO } & BOD & COD & TBC & TCC & TFC & MR & AP & DEH & TN \\
\hline DO & & $0.862^{* *}$ & $0.897^{* *}$ & $-0.916^{* *}$ & $-0.913^{* *}$ & $-0.756^{* *}$ & $-0.938^{* *}$ & $-0.926^{* *}$ & $-0.764^{* *}$ & $-0.832^{* *}$ \\
BOD & $0.862^{* *}$ & & $0.977^{* *}$ & $-0.988^{* *}$ & $-0.956^{* *}$ & $-0.914^{* *}$ & $-0.981^{* *}$ & $-0.906^{* *}$ & $-0.918^{* *}$ & $-0.937^{* *}$ \\
COD & $0.897^{* *}$ & $0.977^{* *}$ & & $-0.991^{* *}$ & $-0.927^{* *}$ & $-0.926^{* *}$ & $-0.989^{* *}$ & $-0.941^{* *}$ & $-0.901^{* *}$ & $-0.933^{* *}$ \\
TBC & $-0.916^{* *}$ & $-0.988^{* *}$ & $-0.991^{* *}$ & & $0.959^{* *}$ & $0.925^{* *}$ & $0.996^{* *}$ & $0.927^{* *}$ & $0.921^{* *}$ & $0.948^{* *}$ \\
TCC & $-0.913^{* *}$ & $-0.956^{* *}$ & $-0.927^{* *}$ & $0.959^{* *}$ & & $0.810^{* *}$ & $0.962^{* *}$ & $0.867^{* *}$ & $0.843^{* *}$ & $0.859^{* *}$ \\
TFC & $-0.756^{* *}$ & $-0.914^{* *}$ & $-0.926^{* *}$ & $0.925^{* *}$ & $0.810^{* *}$ & & $0.894^{* *}$ & $0.787^{* *}$ & $0.980^{* *}$ & $0.975^{* *}$ \\
MR & $-0.938^{* *}$ & $-0.981^{* *}$ & $-0.989^{* *}$ & $0.996^{* *}$ & $0.962^{* *}$ & $0.894^{* *}$ & & $0.952^{* *}$ & $0.890^{* *}$ & $0.928^{* *}$ \\
AP & $-0.926^{* *}$ & $-0.906^{* *}$ & $-0.941^{* *}$ & $0.927^{* *}$ & $0.867^{* *}$ & $0.787^{* *}$ & $0.952^{* *}$ & & $0.757^{* *}$ & $0.843^{* *}$ \\
DEH & $-0.764^{* *}$ & $-0.918^{* *}$ & $-0.901^{* *}$ & $0.921^{* *}$ & $0.843^{* *}$ & $0.980^{* *}$ & $0.890^{* *}$ & $0.757^{* *}$ & & $0.980^{* *}$ \\
TN & $-0.832^{* *}$ & $-0.937^{* *}$ & $-0.933^{* *}$ & $0.948^{* *}$ & $0.859^{* *}$ & $0.975^{* *}$ & $0.928^{* *}$ & $0.843^{* *}$ & $0.980^{* *}$ & \\
\hline
\end{tabular}

$\mathrm{TBC}=$ Total Bacterial Count, $\mathrm{TCC}=$ Total Coliform Count, $\mathrm{TFC}=$ Total Fungal count $\mathrm{MR}=$ Microbial respiration, $\mathrm{AP}=$ Available Phosphorus, $\mathrm{DEH}=$ Dehydrogenase Activity, $\mathrm{TN}=$ Total Nitrogen, $\mathrm{DO}=$ Dissolved Oxygen, BOD= Biochemical Oxygen Demand, $\mathrm{COD}=$ Chemical Oxygen Demand. ${ }^{* *}$ Correlation is significant at the 0.01 level (2-tailed), ${ }^{*}$ Correlation is significant at the 0.05 level (2-tailed). 
Table 3c. Correlations of selected variables in Ijele water sample

\begin{tabular}{lcccccccccc}
\hline & DO & BOD & COD & TBC & TCC & TFC & MR & AP & DEH & TN \\
\hline DO & & $0.925^{* *}$ & $0.982^{* *}$ & $-0.895^{* *}$ & $0.981^{* *}$ & $-0.859^{* *}$ & $-0.984^{* *}$ & $-0.859^{* *}$ & $-0.983^{* *}$ & $-0.954^{* *}$ \\
BOD & $0.925^{* *}$ & & $0.956^{* *}$ & $-0.861^{* *}$ & $0.942^{* *}$ & $-0.897^{* *}$ & $-0.944^{* *}$ & $-0.839^{* *}$ & $-0.972^{* *}$ & $-0.932^{* *}$ \\
COD & $0.982^{* *}$ & $0.956^{* *}$ & & $-0.905^{* *}$ & $0.998^{* *}$ & $-0.898^{* *}$ & $-0.995^{* *}$ & $-0.908^{* *}$ & $-0.994^{* *}$ & $-0.986^{* *}$ \\
TBC & $-0.895^{* *}$ & $-0.861^{* *}$ & $-0.905^{* *}$ & & $-0.899^{* *}$ & $0.972^{* *}$ & $0.929^{* *}$ & $0.955^{* *}$ & $0.887^{* *}$ & $0.934^{* *}$ \\
TCC & $0.981^{* *}$ & $0.942^{* *}$ & $0.998^{* *}$ & $-0.899^{* *}$ & & $-0.884^{* *}$ & $-0.993^{* *}$ & $-0.908^{* *}$ & $-0.988^{* *}$ & $-0.986^{* *}$ \\
TFC & $-0.859^{* *}$ & $-0.897^{* *}$ & $-0.898^{* *}$ & $0.972^{* *}$ & $-0.884^{* *}$ & & $0.913^{* *}$ & $0.945^{* *}$ & $0.885^{* *}$ & $0.931^{* *}$ \\
MR & $-0.984^{* *}$ & $-0.944^{* *}$ & $-0.995^{* *}$ & $0.929^{* *}$ & $-0.993^{* *}$ & $0.913^{* *}$ & & $0.929^{* *}$ & $0.989^{* *}$ & $0.991^{* *}$ \\
AP & $-0.859^{* *}$ & $-0.839^{* *}$ & $-0.908^{* *}$ & $0.955^{* *}$ & $-0.908^{* *}$ & $0.945^{* *}$ & $0.929^{* *}$ & & $0.876^{* *}$ & $0.959^{* *}$ \\
DEH & $-0.983^{* *}$ & $-0.972^{* *}$ & $-0.994^{* *}$ & $0.887^{* *}$ & $-0.988^{* *}$ & $0.885^{* *}$ & $0.989^{* *}$ & $0.876^{* *}$ & & $0.970^{* *}$ \\
TN & $-0.954^{* *}$ & $-0.932^{* *}$ & $-0.986^{* *}$ & $0.934^{* *}$ & $-0.986^{* *}$ & $0.931^{* *}$ & $0.991^{* *}$ & $0.959^{* *}$ & $0.970^{* *}$ & \\
\hline
\end{tabular}

$\mathrm{TBC}=$ Total Bacterial Count, $\mathrm{TCC}=$ Total Coliform Count, $\mathrm{TFC}=$ Total Fungal count $\mathrm{MR}=$ Microbial respiration, $\mathrm{AP}=$ Available Phosphorus, $\mathrm{DEH}=$ Dehydrogenase Activity, $\mathrm{TN}=$ Total Nitrogen, $\mathrm{DO}=$ Dissolved Oxygen, $\mathrm{BOD}=$ Biochemical Oxygen Demand, $\mathrm{COD}=\mathrm{Chemical}$ Oxygen Demand. ${ }^{* *}$ Correlation is significant at the 0.01 level (2-tailed), ${ }^{*}$ Correlation is significant at the 0.05 level (2-tailed).

Table 3d. Correlations of selected variables in Imaka water sample

\begin{tabular}{lcccccccccc}
\hline & DO & BOD & COD & TBC & TCC & TFC & MR & AP & DEH & TN \\
\hline DO & & $0.957^{* *}$ & $0.976^{* *}$ & $-0.936^{* *}$ & $0.981^{* *}$ & $-0.827^{* *}$ & $-0.798^{* *}$ & $-0.960^{* *}$ & $-0.819^{* *}$ & $-0.919^{* *}$ \\
BOD & $0.957^{* *}$ & & $0.972^{* *}$ & $-0.962^{* *}$ & $0.952^{* *}$ & $-0.737^{* *}$ & $-0.808^{* *}$ & $-0.924^{* *}$ & $-0.814^{* *}$ & $-0.942^{* *}$ \\
COD & $0.976^{* *}$ & $0.972^{* *}$ & & $-0.975^{* *}$ & $0.990^{* *}$ & $-0.794^{* *}$ & $-0.820^{* *}$ & $-0.974^{* *}$ & $-0.896^{* *}$ & $-0.976^{* *}$ \\
TBC & $-0.936^{* *}$ & $-0.962^{* *}$ & $-0.975^{* *}$ & & $-0.950^{* *}$ & $0.712^{* *}$ & $0.904^{* *}$ & $0.967^{* *}$ & $0.916^{* *}$ & $0.972^{* *}$ \\
TCC & $0.981^{* *}$ & $0.952^{* *}$ & $0.990^{* *}$ & $-0.950^{* *}$ & & $-0.854^{* *}$ & $-0.818^{* *}$ & $-0.982^{* *}$ & $-0.864^{* *}$ & $-0.944^{* *}$ \\
TFC & $-0.827^{* *}$ & $-0.737^{* *}$ & $-0.794^{* *}$ & $0.712^{* *}$ & $-0.854^{* *}$ & & $0.658^{*}$ & $0.822^{* *}$ & $0.579^{*}$ & $0.670^{*}$ \\
MR & $-0.798^{* *}$ & $-0.808^{* *}$ & $-0.820^{* *}$ & $0.904^{* *}$ & $-0.818^{* *}$ & $0.658^{*}$ & & $0.898^{* *}$ & $0.784^{* *}$ & $0.795^{* *}$ \\
AP & $-0.960^{* *}$ & $-0.924^{* *}$ & $-0.974^{* *}$ & $0.967^{* *}$ & $-0.982^{* *}$ & $0.822^{* *}$ & $0.898^{* *}$ & & $0.899^{* *}$ & $0.939^{* *}$ \\
DEH & $-0.819^{* *}$ & $-0.814^{* *}$ & $-0.896^{* *}$ & $0.916^{* *}$ & $-0.864^{* *}$ & $0.579^{*}$ & $0.784^{* *}$ & $0.899^{* *}$ & & $0.954^{* *}$ \\
TN & $-0.919^{* *}$ & $-0.942^{* *}$ & $-0.976^{* *}$ & $0.972^{* *}$ & $-0.944^{* *}$ & $0.670^{*}$ & $0.795^{* *}$ & $0.939^{* *}$ & $0.954^{* *}$ & \\
\hline
\end{tabular}

$\mathrm{TBC}=$ Total Bacterial Count, $\mathrm{TCC}=$ Total Coliform Count, $\mathrm{TFC}=$ Total Fungal count $\mathrm{MR}=$ Microbial respiration, $\mathrm{AP}=$ Available Phosphorus, $\mathrm{DEH}=$ Dehydrogenase Activity, $\mathrm{TN}=$ Total Nitrogen, $\mathrm{DO}=$ Dissolved Oxygen, $\mathrm{BOD}=$ Biochemical Oxygen Demand, $\mathrm{COD}=\mathrm{Chemical}$ Oxygen Demand. ${ }^{* *}$ Correlation is significant at the 0.01 level (2-tailed).

\section{DISCUSSION}

DO levels less than $3 \mathrm{mg} / \mathrm{L}$ are stressful to most aquatic organisms. Most fish die at $1-2 \mathrm{mg} / \mathrm{L}$. However, fish can move away from low DO areas. Water with low DO from $0.2-0.5 \mathrm{mg} / \mathrm{L}$ are considered hypoxic; waters with less than $0.5 \mathrm{mg} / \mathrm{L}$ are anoxic. The DO standard for sustaining aquatic life is stipulated at $5 \mathrm{mg} / \mathrm{L}$ a concentration below this value adversely affects aquatic biological life, while concentration below $2 \mathrm{mg} / \mathrm{L}$ may lead to death for most fishes (Chapman, 1993). The present findings reported DO values higher than $5 \mathrm{mg} / \mathrm{L}$ in all locations. Hence the DO values obtained in this study are found to be acceptable living conditions for living organisms in water. Hence the pollution of water samples in all the locations with pesticides did not cause significant stress to the aquatic life.

The BOD levels reported in this study were higher than the values reported as the standard EU guidelines of 3.0 to $6.0 \mathrm{mg} / \mathrm{L}$. High BOD levels results in decrease of DO levels because the bacteria are making use of the limited oxygen that is available in water. Due to the low level of dissolved oxygen in water, fish and other aquatic organisms may not survive. The high BOD levels reported in this study is as a result of the several activities such as, defecating, washing, swimming etc. which occurs in the streams. 
Similar results were reported by Akan et al. (2012), they stated that the BOD levels recorded in the entire sampling points, in their study, were higher than the EU guidelines of 3.0 to $6.0 \mathrm{mg} / \mathrm{L}$.

In this study the least COD value of $26.033 \pm 0.401 \mathrm{mg} / \mathrm{L}$ was lower than the WHO limit of $200 \mathrm{mg} / \mathrm{L}$. Conversely, Akan et al. (2012) reported that the least COD value detected at point S2 did exceed the WHO limit of $200 \mathrm{mg} / \mathrm{L}$. The increasing trend in COD concentration in the five sampling point when compared to the WHO standard value is an indication of wastewater dis- charges from settlements along the ChariLogone and Komadugu-Yobe River courses particularly from abattoirs, hotels and hospitals into the lake, and also from surface and ground flows that carry chemicals directly from agricultural field into the Lake (Keith and Plowes, 1997). The pesticide concentrations recovered from the pesticide treated farmland soils indicates the persistence of these pesticides in soils after use on crop plants (as insecticides) and in clearing weeds. However, pesticide concentrations in water samples were not reported because the concentrations obtained were negligible. This might have occurred as a result of biodegradation of the pesticides in water due to the presence of active pesticide degrading microbial populations.

The soils of the farm lands that had been treated with pesticide contained mainly Bacillus, Pseudomonas and Aspergillus species. These bacterial and fungal species have been reported to be good biodegraders of pesticides (Filimon et al., 2012). Increased microbial respiration, dehydrogenase activity, total nitrogen and available phosphorus observed in this study indicates increased microbial activity, which can in turn lead to increased biochemical oxygen demand in water samples. This is however dangerous to the health of living organisms in the aquatic environment. Similar to what was obtained in this study, high total coliform was also reported in the work of Badr et al. (2014). Mahesh and Prasanth (2015) reported that in their study, the range of total viable count $(\mathrm{CFU} / \mathrm{mL})$ and total coliform counts $(\mathrm{CFU} / \mathrm{mL})$ were in the range of $4.3-9.9$ (x104) and $1.43-2.6$ (x 103) respectively. They further reported that most of the sites were found to have high TVC in most of the water samples. Most of the samples were found to have TVC higher than suggested by the Bureau of Indian Standard limits (BIS, 1991). However, in this study the range of total viable counts and total coliform counts were higher than reported by Mahesh and Prasanth (2015). Heterotrophic bacteria commonly respond to pollution of this type by decomposing organic matter and releasing nutrients and energy (Obi et al., 2002). Constant visits to rivers by the populace and by livestock are common in developing countries. Especially, poor rural communities that have limited access to potable clean water and they largely reside near river banks (Mahesh and Prasanth, 2015). As a result, they often utilize river waters for their daily washings and defecation which results in pollution of these water bodies. These activities particularly deteriorate microbial water quality as fecal matter is disposed and the surrounding area is littered with feces.

\section{CONCLUSION}

This study has given indication of the extent of microbial and pesticide pollution; any further addition of wastes may deteriorate the existing hygienic quality of water in these locations. It is recommended that regular microbiological studies including supplemental bacterial indicators should form an integral part of coastal pollution monitoring programs.

\section{REFERENCES}

1. Akan, J.C., Abbagambo, M.T., Chellube, Z.M., Abdulrahman, F.I. (2012). Assessment of Pollutants in Water and Sediment Samples in Lake Chad, Baga, North Eastern Nigeria. Journal of Environmental Protection, 3, 1428-1441.
2. American Public Health Association (1998). Standard Methods for the Examination of Water and Waste Water, 20th Edition., Washington DC.

3. Badr, R., Holial, H., Olama, Z. (2014). Water quality assessment of hasbani river in south Lebanon: Microbiological and Chemical 
Characteristics and their Impact on the Ecosystem. Journal of Global Biosciences, 3(2), 536-551.

4. Beitz, H., Schmidt, H., Herzel, F. (1994). Occurrence, toxicological and ecotoxicological significance of pesticides in groundwater and surface water. In: Börner $\mathrm{H}$. Pesticides in ground and surface water. Springer-Verlag, Berlim.

5. Bureau of Indian Standard, Indian Standard (1991). Indian standards drinking water specification.

6. Chapman, D. (1993). Assessment of Injury to Fish Populations: Clark Fork River NPL Sites, Montana, In: J. Lipton, Ed., Aquatic Resources Injury Assessment Report, Upper Clark Fork Riverm Basin, Montana Natural Resource Damage Assessment Program, Helena, Mont, 1993.

7. Cheah, U.B., Kirkwood, R.C., Lum, K.Y. (1997). Adsorption, desorption and mobility of four commonly used pesticides in Malaysian agricultural soils. Pesticide Science, 50,53-63.

8. De Rossi, C., Bierl, R., Riefstah, J. (2003). Organic pollutants in precipitation: Monitoring of pesticides and polycyclic aromatic hydrocarbons in the region of Trier (Germany). Physics and Chemistry of the Earth, 28, 307-314.

9. Filimon, M.N., Popescu, R., Borozan, A.B., Bordean, D.M., Dumitrescu, G., Voia S.O. (2012). Influence of xenobiotic substances on actinomycete communities in soil. Animal Science and Biotechnologies, 45(2), 221-224.

10. Filizola, H.F., Ferracini, V.L., Sans, L.M.A., Gomes, M.A.F., Ferreira, C.J.A. (2002). Monitoring and evaluation of the risk of contamination by pesticide in surface water and groundwater in the Guaíra region, São Paulo, Brazil. Brazilian Agricultural Research, 37, 659667.

11. Food Agriculture Organization of the United Nations (1996). Control of water pollution from agriculture. GEMS/Water Collaborating Centre-
Canada Centre for Inland Waters, Burlington, Canada.

12. Keith, J. O., Plowes, D. C. H. (1997). Considerations of Wildlife Resources and Land Use in Chad," USAID Technical, Paper 47, 1997.

13. Klimek, B. (2012). Effect of Long-Term Zinc Pollution on Soil Microbial Community Resistance to Repeated Contamination. Bulletin of Environmental Contamination and Toxicology, $8(4), 617-622$.

14. Lourençato, L.F., Favaretto, N., Hansel, F.A., Scheer, A., Junior, L.F.L., Souza, L.C., Dieckow, J., Buch, A.C. (2015). International Journal of Plant \& Soil Science, 5(3), 155-166.

15. Lugushie, J.A., Atabila, A (2012). Effect of Organochlorine Pesticides Usage on Water Quality of Tano River in the Asunafo South District of Brong Ahafo Region of Ghana. Advanced Research in Scientific Areas, 3(7), 1357-1362.

16. Mahesh, V. and Prasanth, S. (2015). Occurrence of pollution indicators in tropical perennial river of Periyar, Southern India. International Journal of Pharmacological Research, 5(10), 264-268.

17. Nagvenkar, G.S., Ramaiah, N. (2009). Abundance of sewage-pollution indicator and human pathogenic bacteria in a tropical estuarine complex. Environmental Monitoring Assessment, $155,245-256$.

18. Obi, C.L., Potgieter, N., Bessong, P.O. and Matsaung, G. (2002). Assessment of the microbial quality of river water sources in rural Venda communities in South Africa. Water S.A., 28, 287292.

19. Oudney, M.B., Ou, Z., Sekela, M., Tuominen, T., Gledhill, M. (2009):Pesticide Multiresidues in waters of the Lower Fraser Vally, British Columbia, Canada. Part1. Surface water. Journal of Environmental Quality, 38 (3), 940-947. 
20. Page, A.L., Miller, R.H., Keeney (eds.) (1982). Methods of soil analysis: Part 2. Chemical and microbiological properties. $2^{\text {nd }}$ ed. Agronomy Series 9, ASA, SSSA, Madison, Wis.

21. Pierzynski, G.M., Sims, J.T., Vance, G.F. (2000). Soils and environment quality. 2 ed. Boca Raton.

22. Tang, X., Zhu, B., Katou, H. (2012). A review of rapid transport of pesticides from sloping farmland to surface waters: Processes and mitigation strategies. Journal of Environmental Sciences, 24,351-361.

23. Vignesh, S., Muthukumar, K., Santhosh, G. M., Arthur, J. R. (2013). Microbial pollution indicators in Cauvery river, southern India. In Mu. Ramkumar (Ed.), On a Sustainable Future of the Earth's Natural Resources, Springer earth system sciences. 363-376

24. Williamson, S., Ball, A., Pretty, D. (2006) Trends in pesticides use and drivers for safer pest management in four African countries. Crop Protection, 27: 1327-1334. 